UDC 656.073.7

DOI 10.26906/eip.2019.4(75).1861

JEL classification: M38

\title{
FOREIGN EXPERIENCE IN USING LOGISTICS, MARKETING MANAGEMENT AND THE POSSIBILITY OF ITS ADAPTATION IN UKRAINE
}

\author{
Olena Zerniuk*, Ph.D., Associate Professor \\ Mariia Hunchenko**, Ph.D., Associate Professor \\ Yuri Snisar \\ Nazar Sonnyk \\ National University «Poltava Yuri Kondratyuk Polytechnic» \\ *ORCID 0000-0003-2152-8800 \\ ** ORCID 0000-0003-2488-6566 \\ (C) Zerniuk O., 2019 \\ (C) Hunchenko M., 2019 \\ (C) Snisar Y., 2019 \\ (C) Sonnyk N., 2019 \\ Стаття отримана редакиісю 21.11.2019 р. \\ The article was received by editorial board on 21.11.2019
}

Introduction. World experience of management shows that popular practice of competitiveness of enterprises and organizations is the concept of logistics management. It acquires special relevance in the period of crisis, when enterprises must organize their activities in such a way as the costs minimization associated with the movement and storage of inventory from the primary source to the end user. At the same time, it is important to pay attention to the close relationship of marketing and logistical concepts in the formation of modern policy of international trade. In fact, if it defines general strategic goals, logistics by different factors, and most of the price, actively influences their achievement. Logistic operations in relation to the rational way of transportation in the mode of transport, the carrier, and optimum routing can significantly reduce the cost of distribution system and increase the capabilities of marketing pricing policy. Expenses in distribution to warehousing, customs procedures and, especially, transport costs in comparison with the cost production and affect the prices of goods, and, consequently, to meet the market needs of consumers. Logistics helps implement marketing pricing schemes.

Analysis of recent researches and publications. Research of the place of Ukraine in the modern world logistics system was described by a lot of domestic scientists: Smerchevska S.V., Kryvoviaziuk I.V., Volynchuk Yu.V., Blyndiuk R.V., Dashzyev M.A., Fedoryshyn E., Kuchkova O.V., Arkhireiska N.V., and others. But studying the experience of the leading countries of the world regarding the development of logistics management with a marketing component and defining the possibilities of its implementation in Ukraine is relevant, because there are problems in this industry and they must be addressed.

The purpose of the article is to study the ranking of countries according to LPI index, identifying Ukraine's problems, causing its low rating and finding possible ways to implement foreign experience in modern logistics management to improve Ukrainian logistics system.

Main material and results. Foreign experience convinces us that the use of logistics can significantly reduce the time interval between the purchase of raw materials and semi-finished products and the supply of the finished product to the consumer, contributes to the sharp reduction of material stocks, accelerates the process of obtaining information, increases the level of service [1, p. 33]. With the use of modern logistics control flow process can save up Logistic costs $1 \%$ equivalent in increasing sales by $10 \%$. Logistics is one of the most dynamic and important sectors of the economy of developed countries, which accounts for about $10 \%$ of GDP [2, p. 232].

According to the World Bank, in terms of the development of logistics industry (Logistics Performance Index (LPI), Ukraine in 2018 took 66 positions from 160 countries of the world. The first places in logistics ranking were occupied by Germany, Sweden, Belgium, Austria and Japan. In addition, the top ten leaders LPI comprise the Netherlands, Singapore, Denmark, the United Kingdom and Finland. China 
was on the 26 positions (one step above the ranking 2016). India has not got the first thirty, but it appeared at the 44 place, which at 10 positions above its indicator 2014. Rating of countries according to LPI index in 2014-2018 biennium shows that Ukraine's place in the world competition is now unstable. Worse, the dynamics of this indicator are not positive (table. 1).

Table 1

Logistics Efficiency Index (LPI) Different countries of the world [3]

\begin{tabular}{|l|c|c|c|c|}
\hline \multirow{2}{*}{ Country } & \multicolumn{3}{|c|}{ Years: } & Deviation (+;-) in \\
\cline { 2 - 5 } & 2014 & 2016 & 2018 dated 2014. \\
\hline Germany & 4 & 1 & 1 & 3 \\
\hline Poland & 31 & 33 & 41 & 0 \\
\hline Austria & 22 & 7 & 10 & 18 \\
\hline Finland & 24 & 15 & 49 & 14 \\
\hline Croatia & 55 & 51 & 66 & -5 \\
\hline Ukraine & 61 & 80 & 113 & -19 \\
\hline Moldova & 94 & 93 & 32 & 8 \\
\hline Hungary & 40 & 33 & 39 & 12 \\
\hline Slovakia & 51 & 43 & 103 & -4 \\
\hline Belarus & 99 & 120 & & \\
\hline
\end{tabular}

As seen in table data. 1.5 , in 2016Ukraine dropped from 61 to 80 positions. This is because other countries are developing their logistics systems more rapidly than our state. Another reason for the decrease in the rating is the complex socio-economic and political situation in the country. In 2018, our country has risen to 66 positions. Ukraine is located between Serbia and Egypt, and in the post-Soviet space was the third after Estonia (3.31 points and 36 positions) and Lithuania (3.02 points and 54 positions). In 2014, Germany took 4th place in the rating, and already in 2016 became a standard country, Poland in 2018 again took 31 positions, thus demonstrating a rather stable position. Croatia in $2018-49$, Hungary -32 , Slovakia -39 positions. The worst situation in Belarus, which in 2018 was on 103 positions, although in 2014 there was a 91 position. It is realized the pace of development logistic and Moldova, which in a short period of time reduced its level of 19 positions (2014 - 94 positions, 2018 - 113 positions respectively). Complete list of Burundi, Angola and Afghanistan [3].

From our analyzed data it becomes clear that by the development of logistics Ukraine is seriously lagging behind the leading countries and neighboring countries, which is due to a number of problems of subjective and objective nature (Fig. 1). Some of these problems are inherent in other countries of the postSoviet space, which negatively affects their rating performance.

Therefore, today there is an urgent need to study foreign experience in the use of logistics management and the possibilities of its adaptation in Ukraine. From the point of view of the study of effective mechanisms for the formation of the National Model of logistics management the most attention, in our opinion, deserve a system of logistics The World Bank, calculating the LPI, enjoys weighted average value of the following criteria:

1) Efficiency of the process of customs clearance (speed, simplicity and predictability of formalities);

2) Quality of logistics infrastructure (e.g. ports, railways, roads, information technologies);

3) Organization of the international supply process;

4) Competence and quality of logistic activity;

5) Awareness, possibility of tracking and monitoring of cargoes;

6) Timeliness of Logistics services [3].

These indicators are aimed at improving the quality of the logistics services provided by SP to blackberries around the world and allow to determine the priority goals in developing the logistics activities of each individual country. Dynamics of changes in the weighted criteria of the index of logistics efficiency of Ukraine for $2010-2018$ yrs. is presented in table 2. The higher the score, the stronger the position in the country in this category. 


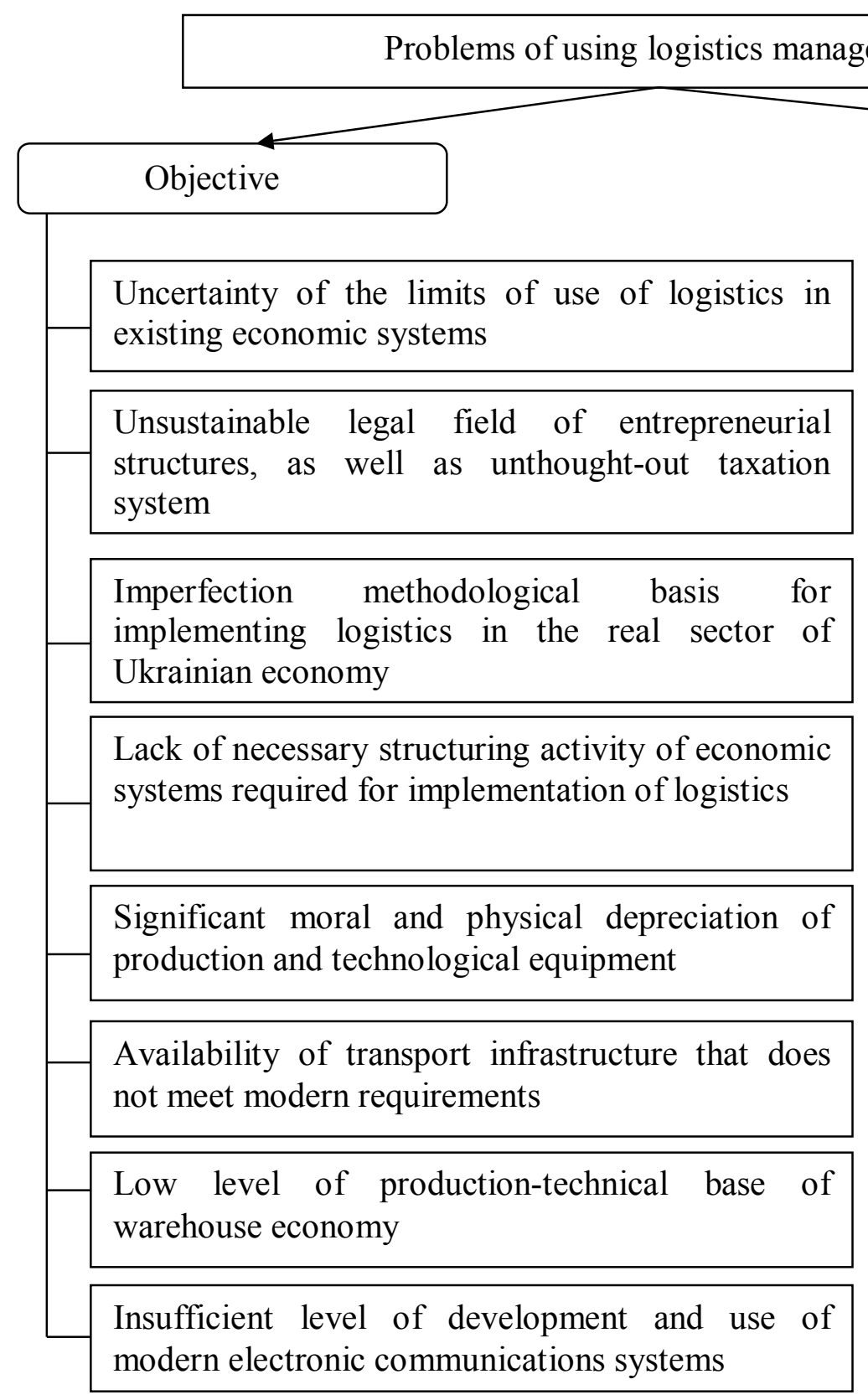

Fig. 1. Main problems associated with the use of logistics management at Enterprises of Ukraine [author's vision]

Table 2

Weighted average Logistical Performance Index criteria

Of Ukraine for 2010-2018 yrs. [3]

\begin{tabular}{|c|l|l|l|l|l|}
\hline \multirow{2}{*}{ Indicator } & \multicolumn{5}{|c|}{ Year } \\
\cline { 2 - 6 } & 2010 & 2012 & 2014 & 2016 & 2018 \\
\hline LPI grade & 102 & 66 & 61 & 80 & 66 \\
\hline LPI rating & 2,57 & 2,85 & 2,98 & 2,74 & 2,83 \\
\hline Customs procedures & 2,02 & 2,41 & 2,69 & 2,30 & 2,49 \\
\hline Infrastructure & 2,44 & 2,69 & 2,65 & 2,49 & 2,22 \\
\hline International transportation & 2,79 & 2,72 & 2,75 & 2,59 & 2,83 \\
\hline Logistic competence & 2,59 & 2,85 & 3,84 & 2,55 & 2,84 \\
\hline Cargo tracking & 2,49 & 3,15 & 3,2 & 2,96 & 3,11 \\
\hline Timeliness of delivery & 3,06 & 3,31 & 3,51 & 3,51 & 3,42 \\
\hline
\end{tabular}


As seen in table. 2, Ukraine does not show any sustainable development on any of the indicators. This indicates the instability of our logistics system, and therefore the appropriate level of trust in it. All this reduces the competitiveness of our economy in the world. Therefore, it is necessary to turn to the experience of countries that are more successful in logistics management and try to use their experience.

The European Union successfully operates a significant number of large transport and logistics companies that have an extensive network of representative offices, warehouses, terminals, complexes throughout the European region and beyond. To optimize traffic flows and facilitate the passage of customs procedures are created global unions, which spread its influence in different regions of the world [6, p. 128].

The principles of development of the European logistics system are enshrined in the Logistics Development Program (Logistics Action Plan) of 2007, which defines specific directions of improvement of the European Union logistics system. The main ones are: development of the system of electronic information about freight transport, improvement of the system of training of specialists, simplification of logistic processes, strengthening of requirements for environmentally friendly cargo transport, used in urban and Long-distance freight.

The system of logistics management of modern China is inferior to European by the level of organization, but much ahead of Ukrainian. The modern Chinese logistic market attracts attention of foreign enterprises, which actively invest in its further development. Recently, FedEx, UPS, TNT and other transcontinental corporations have been actively cooperating with large logistics companies in China. Today in the east of this country already formed 4 large logistic areas, which through various methods stimulate the development of central and western regions of the country.

Hudz P.V. states that the emergence of Chinese logistics is associated with a number of problems, the most important of which is the specialization of local operators on the a narrow segment of logistics services, which weakens the inter-economic consolidation and limits the development of the overall logistics system of the country [7, p. 140]. Thus, nowadays, the so-called "WFOE" - Wholly Foreign-Owned Enterprises are wholly owned companies in China. The specific peculiarity of the functioning of the logistics management system in China is that, unlike the EU and Ukraine countries, investment in logistics infrastructure is carried out exclusively by the private sector, and the state's actions are aimed at supporting Enhancing integration, coordination and standardization.

Conclusions. Summarizing the above, we can conclude that overseas awareness of the role of logistics in the economic growth of countries and regions occurred a long time ago. This influenced the formation and development of the system of internal and external logistic ties of developed foreign countries. The analysis of logistics development dynamics in developed countries shows that in the case of each country, the choice of a particular theoretical apparatus, methodology and practical tools Need, which was formed under the influence of defining factors as the level of development of productive forces, peculiarities of specialization and cooperation on the domestic and international markets, level of technological development, political situation, character and level of development of market relations, national and social traditions of the State and institutions.

Thus, at this point of time, a steady leadership in the level of logistics is occupied by Western Europe and the developed Asian regions, but the logistics systems of developed countries in the ranking of LPI are not a perfect model for copying, since each of them, firstly, is not devoid of certain shortcomings, and secondly focused on the specifics of a particular region. For foreign logistics and its investment in different countries for individual and scenarios on the peculiarities of national economic policy, geographical, demographic features, urbanization and the level of development of the general infrastructure of specific regions. The common feature of logistic systems of developed European, American and Asian markets is to focus on modernization through the introduction of modern Information technologies and the expanding range of IT services. Quite low estimates of logistics efficiency index and key logistic indicators of Ukrainian logistics competence indicate that this sphere needs special attention.

\section{REFERENCES:}

1. Nyzhnyk I.V. Lohistyka $\mathrm{v}$ menedzhmenti promyslovykh pidpryiemstv: teoriia ta praktyka zastosuvannia. [Logistics in Management of industrial enterprises: Theory and practice of application] / I. V. Nizhnyk// Visnyk Khmelnytskoho natsionalnoho universytetu. Ekonomichni nauky [Visnyk of Khmelnytsky National University. Economic sciences]. - 2014. - No 5 (1). - P. 31-34.

2. Trushkina N.V. Lohistychni kontseptsii na promyslovomu pidpryiemstvi $\mathrm{v}$ umovakh hlobalizatsii rynku [Logistics concepts in an industrial enterprise in the conditions of market globalization] / N. V. Trushkina, Yu. V. Drachuk, Yu. S. Zaloznova // Problems of the economy [Problemy ekonomiky]. - 
2016. - No 3. - P. 228-238.

3. The World Bank Working for a World Free of Poverty. URL: https://lpi.worldbank.org/international/scorecard/radar/254/C/HTI/2018\#chartarea

4. Shevtsiv L. Stratehichne lohistychne upravlinnia diialnistiu mashynobudivnykh pidpryiemstv v umovakh yevrointehratsiinykh protsesiv [Strategic logistical management of engineering enterprises activity in the conditions of Euro integration processes] / L. Shevtsiv // Visnyk Dnipropetrovskoho universytetu. Seriia: Svitove hospodarstvo ta mizhnarodni ekonomichni vidnosyny [Bulletin of the University of Dnipropetrovsk. Series: World economy and international economic relations]. - 2017. - No 9 (25). - P. 118-136.

5. Shandrivska O.E. Kompleksnyi analiz rynku lohistychnykh posluh v Ukraini [The complex analysis of the logistics services market in Ukraine] / O.E. Shandrivska, L.Yu. Shevtsiv // Aktualni problemy ekonomiky [Actual problems of the economy]. - 2016. - No 7. - P. 163-173.

6. Katma V.I. Sutnist ta rol lohistychnoho upravlinnia v systemi upravlinnia pidpryiemstvom [Essence and role of logistics management in the system of enterprise Management] / V.I. Katskma // Ekonomichnyi analiz: zb. nauk. prats. - Ternopil: Vydavnycho-polihrafichnyi tsentr Ternopilskoho natsionalnoho ekonomichnoho universytetu "Ekonomichna dumka" [Economic Analysis: Sciences. Works. Ternopil: Publishing and Polygraphic Center of Ternopil National Economic University "Economic thought"], 2016. - Vol. 23. - No 2. - P. 60-65.

7. Hudz P.V. Analiz zarubizhnoho dosvidu zastosuvannia systemnoho upravlinnia lohistychnoiu diialnistiu [Analysis of foreign experience of the system management of logistics activity] / P.V. Hudz, T.I. Ostapenko // Biznes Inform [Business inform]. - 2011. - No 4. - P. 139-142.

8. Kuchkova O.V. Lohistychnyi potentsial Ukrainy v mizhnarodnomu reitynhu [Logistic potential of Ukraine in the international rating] / O.V. Kuchkov, N.V. Archireyska // Byznes-ynform [Business inform]. - 2017. - No 1. - P. 39-43.

UDC 656.073.7

JEL classification: M38

Зернюк Олена Вячеславівна, кандидат технічних наук, доцент. Гунченко Марія Володимирівна, кандидат економічних наук, доцент. Снісар Юрій. Сонник Назар. Національний університет «Полтавська політехніка імені Юрія Кондратюка». Зарубіжний досвід використання логістики, управління маркетингом та можливість його адаптації в Україні. Дослідженно зарубіжний досвід у сфері логістичного та маркетингового менеджменту. Розкрит результати аналізу рейтингу країн за індексом LPI, а також визначають проблеми України, що спричиняють ії низький рейтинг за цим показником. Наведено пропозиції щодо можливостей імплементації закордонного досвіду в сучасному управлінні логістикою для поліпшеня української логістичної системи. Метою статті є дослідження рейтингу країн за індексом LPI, виявлення проблем України, що спричиняють іiі низький рейтинг та пошук можливих шляхів імплементації закордонного досвіду в сучасному управлінні логістикою для поліпшення української логістичної системи. Проведено аналіз індексу ефективності логістики різних країн світу. Встановлено, що у 2016 р. Україна опустилася з 61-ї на 80ту позицію. Це пояснюється тим, що інші країни розвивають свої логістичні системи більш швидкими темпами, ніж наша держава. Ще однією причиною зниження рейтингу є складна соціально-економічна та політична ситуація в країні. Зроблено висновок, що за розвитком логістики Україна серйозно відстає від провідних країн і країн-сусідів, що обумовлено низкою проблем суб'єктивного та об'єктивного характеру. Деякі з них притаманні й іншим країнам пострадянського простору, що негативно впливає і на їхні рейтингові показники. Зроблено висновок про те, що за кордоном усвідомлення ролі логістики в економічному зростанні країн і регіонів відбулося досить давно. Це вплинуло на формування і розвиток системи внутрішніх і зовнішніх логістичних зв'язків розвинених зарубіжних країн світу. Аналіз динаміки розвитку логістики в розвинутих країнах показує, що стосовно кожної країни вибір конкретного теоретичного апарату, методології та практичного інструментарію логістики був обумовлений конкретною економічною потребою, яка формувалася під впливом таких визначальних чинників, як рівень розвитку продуктивних сил, особливості спеціалізації та кооперування на внутрішньому й міжнародному ринках, рівень технологічного розвитку, політична ситуація, характер і рівень розвитку ринкових відносин, національні та соціальні традиції конкретної держави й інститутів. 
Ключові слова: логістика, управління логістикою, управління маркетингом, індекс ефективності логістики (IЕЛ), ринок логістики, управління логістичними процесами.

\section{UDC 656.073.7}

JEL classification: M38

Zerniuk Olena, Ph.D., Associate Professor. Hunchenko Mariia, Ph.D., Associate Professor. Snisar Yuriy. Sonnyk Nazar. National University «Yuri Kondratyuk Poltava Polytechnic». Foreign experience in using logistics, marketing management and the possibility of its adaptation in Ukraine. The article is devoted to the study of foreign experience in the field of logistics and marketing management. The authors disclose the results of the analysis of the rating of countries by the LPI index, as well as identify the problems of Ukraine, which cause its low rating on this indicator. The article offers suggestions on the possibilities of implementing foreign experience in modern logistics management to improve the Ukrainian logistics system.

Key words: logistics, logistics management, marketing management, logistics performance index (LPI), logistics market, logistics process management.
UDC 656.073.7

JEL classification: M38

Зернюк Елена Вячеславовна, кандидат технических наук, доцент. Гунченко Мария Владимировна, кандидат экономических наук, доцент. Снисар Юрий. Сонник Назар. Национальный університет «Полтавская политехника имени Юрия Кондратюка» Зарубежный опыт использования логистики, управления маркетингом и возможность его адаптации в Украине. Исследован зарубежный опыт в сфере логистического и маркетингового менеджмента. Раскрыты результаты анализа рейтинга стран по индексу LPI, а также определены проблемы Украины, которые стали причиной ее низкого рейтинга по этому показателю. Приведены предложения относительно возможностей имплементации зарубежного опыта в современном управлении логистикой для улучшения украинской логистической системы. Целью статьи является исследование рейтинга стран по индексу LPI, выявление проблем Украины, которые вызывают ее низкий рейтинг, и поиск возможных путей имплементации зарубежного опыта в современном управлении логистикой для улучшения украинской логистической системы. Проведен анализ индекса эффективности логистики разных стран мира. Установлено, что в 2016 г. Украина опустилась с 61-й на 80-ю позицию. Это объясняется тем, что другие страны развивают свои логистические системы более быстрыми темпами, чем наше государство. Еще одной причиной снижения рейтинга является сложная социальноэкономическая и политическая ситуация в стране. Сделан вывод о том, что за рубежом осознание роли логистики в экономическом росте стран и регионов произошло довольно давно. Это повлияло на формирование и развитие системы внутренних и внешних логистических связей развитых зарубежных стран. Анализ динамики развития логистики в развитых странах показывает, что относительно каждой страны выбор конкретного теоретического аппарата, методологии и практического инструментария логистики был обусловлен конкретной экономической потребностью, которая формировалась под влиянием таких определяющих факторов, как уровень развития производительных сил, особенности специализации и кооперирования на внутреннем и международном рынках, уровень технологического развития, политическая ситуация, характер и уровень развития рыночных отношений, национальные и социальные традиции конкретного государства и институтов.

Ключевые слова: логистика, управление логистикой, управление маркетингом, индекс эффективности логистики (LPI), рынок логистики, управление логистическим процессом. 